\title{
Maxims Deviation and Politeness Scale of Uang Panai Mahar Film by Using Leech's Perspective
}

\author{
Juflyn Alim, Hanip Pujiati, Siti Gomo Attas, Eva Leiliyanti \\ Universitas Negeri Jakarta, Indonesia \\ juflynalim@gmail.com
}

\section{Abstract}

The lack of knowledge about the application of maxims and politeness scale in everyday life cause more violation of politeness in communication. Speech deviations also occur in the Uang Panai Mahar film which raises the cultural theme of a moral message..This study aims to discuss and describe the maxims deviation and politeness conversation from film. The data of this study are the form of maxims deviation and politeness scale by using Leech perspective. The data source in this study is Uang Panai Mahar film, which published by Makita Cinema Production, on August 25, 2016. The film lasted for 1 hour, 59 minutes and 42 seconds. This study used descriptive qualitative method. This study found out some of maxims deviations and politeness scales, they were 1) deviation of wisdom, 2) deviation of generosity, 3) deviation of rewards, 4) deviation of simplicity, 5) deviation of accuracy and 6) deviation of sympathy. Meanwhile the politeness scale of this film were 1) the loss and gain scale, 2) the choice scale, 3) the sustainability scale and 4) social distance scale.
Keywords

politeness in language;

maximum deviation and

scale; film panai

\section{Introduction}

Language is the raw material in communicating in everyday life. Communication activities are the most basic things in human life to interact with each other. The use of language as a medium for communication is often influenced by social status, economics, education level, age, gender, and so on. The social context makes language dynamic. Furthermore, the use of this language can be felt by the speaker or speech partner, whether the language used in the speech event is polite or still not polite. Considering the use of polite language is the desire of everyone, so that communication can take place properly and to avoid failure in communicating in every speech event.

Levinson in his book entitled "Pragmatics" provides limitation for the notion, "pragmatics is the study of those relations between language and context that are grammaticalized, or encoded in the structure of a language". Pragmatics is a language study that studies the relationship between language and its context. There are two types of contexts, which are social and societal contexts. Social context is a context arises as a result of interaction between community members in a particular social and cultural society. (Supriyadi, 2020)

Speech events can occur in various places, including in social life, formal environments, literary works, films, and so forth. Furthermore, to measure the 
politeness of language is inseparable from the context and purpose of communication, because in different social situations will cause different politeness values. According to (Lubis, 2015) the lack of knowledge about the application of maxims and politeness scale in the form of speech in everyday life causes more and more modesty of communication violations, both realized and unconsciously by the speakers. Maximum deviations and politeness scale of language of a person or group also occur in a film.

Film is a form of literary work that is quite modern and is in demand by all circles. (Ardianto, 2004) expressed his opinion related to film, according to him the word film comes from cinema and tho or phytos which means light and graphie or graph which means picture, which can be simplified to mean a moving picture. Then (Pratista, 2008) also expressed his opinion regarding the film, according to him in general can be classified into two parts that make up a film that is the narrative and cinematic elements. Narrative is more to the elements of the builder from within such as characters, settings, conflicts, and so forth. While cinematic is more on the elements of external builders that improve the quality of the film to be better such as cinematography, editing, sound, and so forth.

After making a brief observation about the maximum deviation and politeness scale of the language in the film. Found irregularities and politeness scale of language in the film Uang Panai Mahar (L). The following are examples of maximal deviations and the politeness scale of Leech's perspective in language:

Tuming : Heee

Abu : What?

Tuming : Your style is like a pickpocket.

The sample conversation snippet above is due to the social distance between the speaker and the speech partner that is too close to allow the speaker or the speech partner to mock one another.

The selection of the Uang Panai Mahar film to be the object of research because the film is a local film with a comedy-romantic genre that elevates the cultural values of the Bugis-Makasaar culture which are conditional on moral messages. Since its release in 2016, the film has been in demand by all those who are proven as said by one of the news Coverage 6. It was reported that after 10 days of airing, the Uang Panai Mahar film was watched by approximately 300 thousand viewers, making it the first regional film to be included in the Indonesian Box Office. The success of this film attracted the attention of many people to just enjoy the film. But those who intend to make this film as an object of research. Because good films are films that can contribute to many parties.

Language politeness research has been conducted by (Gunawan, 2014) which focuses on negative politeness strategies and positive politeness strategies of students. The research data uses the politeness of the perspective of Brown and Levinson's perspective. Based on the results of data analysis, it was found that the strategy of negative politeness of students towards lecturers included the use of indirect expressions, the use of cautious and pessimistic expressions, the use of words of respect, and apologies, while the positive politeness strategies of students towards lecturers in the form of group identity markers, use of pleasantries and presuppositions, use of offers and promises, and look for reasons or ask questions. in interacting with lecturers in the academic discourse at STAIN Kendari. 
Further research on politeness in language was conducted by (Jahdiah, 2016) focusing on various kinds of social communication situations in the Banjar family environment, both when family members interacted in the family, and with other people in public places. The research data uses the politeness of Lakoff's perspective language. The results of the study show that there are eight speech request strategies found in the Banjar language, namely asking, asking, greeting, giving information, suggesting, offering, quoting, and insinuating. Each of these strategies applies the politeness scale raised by Robin Lakoff.

Further research on politeness in language was conducted by (Kusmanto, Prayitno, \& Ngalim, 2019) which focused on words, phrases, and sentences that had positive politeness values and negative comments on Jokowi's Instagram account. A positive politeness strategy was found to be nine forms, namely giving attention, showing optimism, using identity markers, asking questions, involving speakers in communication, intensifying the attention of speakers by dramatizing events and facts, paying attention to the wishes of the speech partners, giving promises, and using jokes. The negative politeness strategy is realized in three forms, namely apologizing, showing pessimism; and using impersonal forms.

Based on some relevant research that has been done, the researcher raises a problem from another perspective, namely seeing the maximum deviation and politeness scale of language using the Leech perspective in the film Uang Panai Mahar (L). This research is important to be carried out considering the film's requirements for moral messages so that researchers deem it necessary to conduct research aimed at identifying and describing the deviations of the maxims and politeness scale of language.

\section{Review of Literature}

\subsection{Uang Panai}

(Mattulada, 1985) Panai money is a sum of money requested by a family of women to the party of men who want to marry a Bugis-Makassar woman. Panai money also has another designation, namely sompa. Sompa is dowry money or a dowry dowry, in accordance with the social status of unmarried women. The essence of the panai money is a sign of respect and appreciation by the men of the Bugis-Makassar woman he wants to marry. Aside from the explanation above, this Panai Money is for parents to see the sincerity of men in applying for their female children. Therefore, if a man fulfills a predetermined amount of money, then the man can be said to be very serious to get married. This culture makes men work diligently and try to raise money to make money to marry a woman they love.

(Lamallongeng, 2007) when men who want to marry Bugis-Makassar women will be asked for some money from the family of the woman's side and the money is called Uang Panai. This happens because of the customary provisions prevailing in the Bugis-Makassar community that more requirements are imposed on men. Almost all costs for the wedding are borne by the men. These funds are: spending money (in Bugis doi menre / panai money) (hereinafter referred to as nai money or doi menre in turn), sompa / dowry, leko / betel nut, mappaota and pallawa tana.

\subsection{Courage in Language}

(Chaer, 2010) expressed his opinion related to the use of good language. According to him, a good language user is that people can communicate well and ethically without being separated from good and correct language acquisition. The big question is whether language speakers have mastered the Indonesian language in a way that is used properly and correctly or not. The answer may have been mastered and perhaps not yet mastered. Given that Indonesian is not the mother tongue for most ethnic groups in Indonesia. The use of good or 
polite language is not only used by one party. This issue was also stated by (Wijana, 2009) the principle of politeness involving two parties, namely self (self) and others (other). In line with the above opinion, (Watts, 2003) states that the use of polite language between the first speaker and the interlocutor may be able to avoid friction in interpersonal communication. Furthermore, stated by (Utami, 2017), according to him, a good speech needs to apply pragmatic principles properly which refers to the principle of politeness.

(Ellen, 2001) politeness is the most important principle in communication. This is done to maintain the feelings of the interlocutor so that good communication is always going on. Then (Markhamah \& Sabardila, 2009) also expressed the opinion of politeness according to them that politeness is merely done so that the speech partner does not feel pressured. This view is in line with opinions (Zamzani, Tadkiroatun Musfiroh, Siti Maslakhah, Ari Listyorini, 2011) politeness in language should be done well and uphold ethics in language. More or less the same opinion about politeness of language comes from (Slamet, 2013) according to him politeness of language is only done to avoid conflict. Furthermore according to (Leech, 1993) according to him politeness language does not only occur in a conversation, more than that how to convey, body gestures, and emotional control also need to be considered in order to avoid failure in communication.

The principle of politeness is divided into six by (Leech, 1993). Here are the details:

a. The maxims of wisdom or tact (maxim maxim) requires that the speaker in communication attempts to provide benefits to the speech partner and minimize losses to the interlocutor.

b. This generosity maxims is that speakers try to maximize losses for themselves and minimize personal gains.

c. The maxim of praise or praise (approbation maxims) is that the speaker tries to give respect to the other person and tries not to give disrespect to others.

d. The maxim of simplicity (modesty maxims) is that speakers try to minimize disrespect for themselves, and maximize respect for the interlocutor.

e. The maxim max agreement (agreement maxims) is that the speaker is expected to be able to give a sense of agreement and minimize the disagreement to the speech partner.

f. This sympathy (sympathy) is, speakers are expected to always give sympathy to their speech partners and minimize antipathy to their speech partners.

In the Leech politeness model, each interpersonal maximum can be utilized to determine the politeness rating of a speech. Furthermore (Rahardi, 2005) states that the scale of Leech politeness is divided into five.

a. Cost benefit scale or the scale of losses and gains, focuses on the size of the losses and gains caused by the speech event. Speakers try to provide benefits to the interlocutor then the communication that is established will feel more polite. Conversely, if in communicating speakers try to find personal gain and maximize losses to the speech partner, the communication that is established will be considered impolite.

b. Optionality scale or scale of choice, this scale emphasizes the speakers and speech partners to offer several choices to be chosen. These choices determine whether or not polite expressions are conveyed. The more choices offered, the more polite the expression. Conversely the fewer choices offered, or even choose something that is not offered in the choice, the expression is considered impolite.

c. Indirectness scale or scale of unsustainability scale is explained that communication is done directly and indirectly. Communication indirectly is considered more polite, rather than done directly. 
d. Authority scale refers to the relationship of social status between speakers and interlocutors in the speech event. The farther the distance of social rank (rank rating) between the speaker and the speech partner, the speech used will tend to be more polite. On the other hand, the closer the social status ranking between the two, the less the politeness rating of speech used in speaking will decrease

e. The social distance scale refers to the distance of the social distance between the speaker and the speech partner. If the social distance that is too far between the speaker and the interlocutor, then the communication will have the potential to be more polite. Conversely, if the close social distance between the speaker and the interlocutor, then the communication that takes place will potentially be impolite. follows:

(Pranowo, 2009) states the factors that cause deviations in politeness maxims as
a. Direct criticism with harsh words
b. Impulse of the speaker's emotions
c. Protecting opinions
d. Deliberately accusing interlocutors
e. Deliberately cornering the speech partner

\section{Research Method}

This research is descriptive qualitative. Furthermore, the stages of this study apply three stages, namely: 1) the stage of providing data, 2) the stage of data analysis, 3) the stage of presenting the results of data analysis, as stated by (Sudaryanto, 1993). This method is used to produce maximal deviation data and politeness scale in Leech perspective. The data source in this study is the film Uang Panai Mahar (L) published by Makkita Cinema Production, on August 25, 2016, which lasted 1 hour, 59 minutes 42 seconds (1: 59: 42). The research instrument was the researcher herself as a key instrument. Providing data in this study, we used the listening technique followed by the note taking technique. The collected data is then classified and then analyzed.

\section{Discussion}

Based on data analysis that has been done in the Uang Panai Mahar (L) film. Maxims deviation found and politeness scale of language. The data were analyzed based on the politeness of Leech perspective language, namely deviations of wisdom maxim, deviations of generosity maxims, deviations of the maxim of appreciation, deviations of simplicity maxims, deviations of the maxims of agreement, and deviations of sympathies maxims. Then the politeness scale of language includes: scale of loss and profit, scale of choice, scale of unsustainability, and scale of social distance.

\subsection{Perversion of the Maxims Wisdom}

This policy maxim requires the speaker in communicating to try to provide benefits to the speech partner and minimize losses to the interlocutor. Therefore, if the speaker tries to provide benefits to the interlocutor then the communication that is established will feel more polite. Conversely, if in communicating the speaker tries to seek personal gain and maximize 
losses to the speech partner, the communication that is established will be considered impolite.

Based on the results of data analysis, it is found expressions that are considered to deviate from the maxim of wisdom in the film Uang Panai Mahar (L). The following snippet of conversation between characters in the following context:

\section{Dialogue 1}

Financial Information: The company where Anca works, is holding a meeting. Discuss one type of car that is not selling in the market.

Employee Work : How about we take part in the exhibition.

Rifki / Company Boss: Where have you been, did you never see, every time there was a car show, it was always included?

The above quote contains deviations from the maxims of wisdom. This is because Rifki, as the company boss, has authority in the meeting room, making speeches that are detrimental to the speech partners. Contextually Rifki is driven by a sense of emotion when delivering a response from one of his work employees when giving an opinion that is considered inappropriate. This is in line with the opinion (Pranowo, 2009) that the cause of impolite in communication is caused by the impulse of the speaker's emotion and protective of the opinion.

\section{Dialogue 2}

Financial Information: Anca and Risna are having dinner together. But Anca was just silent and depressed thinking about how difficult it was to get a panai money of 120 million, as a request from the women's family to marry Risna. Then in that condition, Risna asked about the process of their marriage.

Based on the results of data analysis, it is found expressions that are considered to deviate from the maxim of wisdom in the film Uang Panai Mahar (L). The following snippet of conversation between characters in the following context:

Risna : Are you seriously proposing to me?

Anca : Do you think what I did so far?

The above quote contains deviations from the maxims of wisdom. This is because Anca, as Risna's boyfriend, makes a speech that harms the speech partner. Anca is contextually driven by a sense of emotion when delivering responses to questions from Risna. This is in line with the opinion (Chaer, 2010) according to him, at any time language users, when speaking sometimes driven by a sense of excessive emotion, so there is an impression that the speaker is angry with the interlocutor.

\subsection{Generosity of Maxims of Generosity}

This maxim of generosity is, the speaker tries to maximize losses for himself and minimize personal gain. Therefore, if the speaker tries to maximize the loss of oneself to be considered more polite. Conversely, if the speaker tries to maximize personal gain, then the speaker will be considered impolite. 
Based on the results of data analysis, found expressions that are considered to deviate from the maxim of generosity in the film Uang Panai Mahar (L). The following snippet of conversation between characters in the following context

\title{
Dialogue 3
}

Inductive Information: Ash and Tuming are rushing to the port to pick up Anca who has just returned from migrating. However, in the middle of the road their motorcycle broke down. Then they took the initiative to contact Anca.

\author{
Abu : You called Anca! \\ Tuming : How do you want to be contacted if your HP is Lowbet.
}

The above quote contains deviations from the generosity. This is because the words of Abu benefit himself, by asking him to call Anca. Abu's attitude is considered impolite, as opinion (Utami, 2017) according to him the good communication of speakers is expected to use pragmatic principles correctly, one of which is politeness maxim.

\section{Dialogue 4}

Financial Information: Farhan's father wants to match Farhan with Risna. However, Farhan prefers Risna's sister who was unknown to her father before.

Based on the results of data analysis, found expressions that are considered to deviate from the maxim of generosity in the film Uang Panai Mahar (L). The following snippet of conversation between characters in the following context:

Farhan : That father never understood

Farhan's father : Farhan! You know, I don't like being denied.

The above quote contains deviations from the generosity. This is because the words of Farhan's father who benefit themselves, without considering farhan's wishes. Farhan's father's attitude is also considered impolite because it is driven by emotions. The same thing was stated by (Chaer, 2010) according to him, from time to time language users, when speaking sometimes driven by a sense of excessive emotion, so there is an impression that the speaker is angry with his speech partner

\subsection{Maxims Award Deviations}

The maxim of this award is that speakers always try to give respect to the interlocutor and try not to give disrespect to others. Therefore the maxims of appreciation presumably speakers do not insult each other, ridicule each other and denigrate the other party.

Based on the results of data analysis, found expressions that are considered to deviate from the maxim of appreciation in the film Uang Panai Mahar (L). The following snippet of conversation between characters in the following context:

\section{Dialogue 5}

Inductive Information: After Anca and Risna go together in the car Then Anca suddenly started the conversation. 
Anca : How is your work going well?

Risna : Yes, smooth, no problems. If you? Don't explain, I already know.

The above conversation contains deviations from the maxim of appreciation. A distorted test is conducted by Risna which we can examine based on the sentence "Don't explain, I already know". The sentence is intended to undermine Anca's capacity to find work, and to indicate that Anca will have difficulty finding work. As stated by (Chaer, 2010), according to him, the conversation becomes impolite, this happens because the penatsu intentionally wants to discredit or demean the speech partner, making the speech partner helpless.

\subsection{Maxims Simplicity Deviations}

This maxim of simplicity is that speakers try to minimize disrespect for themselves, and maximize respect for the interlocutor. Speakers are considered impolite when speakers are self-favoring. However, on the other hand, the speaker is considered polite when reducing self-praise when talking.

Based on the results of data analysis, found expressions that are considered to deviate from the maxim of simplicity in the film Uang Panai Mahar (L). The following snippet of conversation between characters in the following context:

\section{Dialogue 6}

Indective Information: When Anca wants to apply for a job at a company. Then the Company Boss reads Anca's job application letter.

Company Boss : Anca. I am interested in. But I know what your strengths are

Anca $\quad:$ I am a person who is always confident and full of confidence, sir.

The conversation above contains a deviation of simplicity, where Anca elevates herself when she wants to apply for work. So as to make the interlocutor assume that Anca is less humble. As according to (Chaer, 2010), according to him polite speech is a speech that humbles itself. Departing from this opinion, it is clear that the sentence delivered by Anca is not humble, but exalts itself.

\subsection{Maxims Agreement deviations}

The maximum agreement is that the speaker is expected to be able to give a sense of agreement and minimize the feeling of disapproval to the speech partner. Speakers will be considered polite when always trying to maximize a sense of agreement with the ongoing conversation. Conversely, speakers are considered impolite when maximizing their disapproval of what is being said.

Based on the results of data analysis, found expressions that are considered to deviate from the maxim of consensus in the film Uang Panai Mahar (L). The following snippet of conversation between characters in the following context:

\section{Dialogue 7}

Inductive Information: Anca with her parents and two friends Tuming and Abu. Anca started the conversation, if Risna asked her boyfriend to be proposed. 
Anca's mother : Do you think getting married is easy? From where you can get cash

Anca

: Ouch. Mama. Not giving us support.

The conversation above which was expressed by Anca's mother was considered not polite, because it did not give a sense of support or approval what was expected by Anca. As stated by (Zamzani, Tadkiroatun Musfiroh, Siti Maslakhah, Ari Listyorini, 2011) utterances that maximize speech compatibility with others are considered more polite. Thus it can be said that what was conveyed by Anca's mother was considered impolite.

\subsection{Maxims Agreement deviations}

The maxim of this conclusion is that the speaker is expected to always give sympathy to the speech partner and minimize the feeling of antipathy to the speech partner. Speakers are considered polite when always giving sympathy to the speech partners. Conversely, speakers are considered impolite when maximizing their antipathy to their interlocutors.

Based on the results of data analysis, found expressions that are considered to deviate from the maxim of sympathy in the film Uang Panai Mahar (L). The following snippet of conversation between characters in the following context:

\section{Dialogue 8}

Inductive Information: Tuming and ash feeling hungry, so hurry to the food vendor's place.

Tuming : Auntie, I'm hungry, I haven't eaten since morning, no one reminds me. Food Trader : Hi, this is a place to eat, not a place to talk.

The conversation above shows the antipasti feeling carried out by food vendors. As stated by (Zamzani, Tadkiroatun Musfiroh, Siti Maslakhah, Ari Listyorini, 2011) polite expressions, one of which is always giving sympathy to others. Thus the sentence expressed by food vendors is considered less polite

\subsection{Scale of Losses and Benefits}

This scale is the speaker trying to always have a big soul, which emphasizes the benefits to other parties rather than the speakers themselves. Starting from the utterance that is delivered with the principle the greater the benefit of the speech partner, the more polite the expression will be. Conversely the greater the losses suffered by the speech partner, the skill can be said to be impolite.

Based on the results of data analysis, found expressions that are considered to deviate from the scale of losses and gains in the film Uang Panai Mahar (L). The following snippet of conversation between characters in the following context:

\section{Dialogue 9}

Inductive Information: Farhan's father discussed with Risna's parents with the intention of matching Farhan and Risna.

Farhan's father

: Farhan and Risna used to be very close. Very close, love monkeys! 
Risna's father and mother : I don't mind, anyway Anca isn't officially binding! I don't like it anymore when bargained again. If the story goes like this, just look for another!

The conversation above contains deviations from the scale of losses and profits. The deviation came from Risna's father and mother who tried to make a profit by marrying their child to a rich kid, without thinking about the benefits of Risna who wanted to marry a lover she loved. This is in line with what was stated by (Rahardi, 2005), according to him, the more the phrase is detrimental to the speaker, then the expression will be considered polite. Conversely, if the expression benefits the speaker, the expression is considered impolite.

\subsection{Scale of Choice}

This scale emphasizes the speakers and speech partners to offer several options to choose from. These choices determine whether or not polite expressions are conveyed. The more choices offered, the more polite the expression. Conversely, the fewer choices offered, or instead choose something that is not offered in the choice, the expression is considered impolite.

Based on the results of data analysis, found expressions that are considered to deviate from the choice scale in the film Uang Panai Mahar (L). The following snippet of conversation between characters in the following context:

\section{Dialogue 10}

Financial Information: Anca who is dizzy looking for work with her two best friends.

Tuming and Abu : You just apply to be honorary, or you better be a multi-level marketing (MLM) or an entertainment business by making a band.

Anca : "Anca looks nodding". Then he chose to follow his girlfriend Risna to apply for work in the Car Dialer.

The conversation above was found to be a deviation from the scale of choices made by Anca. Where Tuming and Ash as Anca's best friend offer employment options to Anca. But Anca did not choose a job from one of the choices offered, instead chose the job offered by her boyfriend Risna. This is in line with what was stated by (Rahardi, 2005) according to him, the more an expression allows the speaker or interlocutor to choose from several choices, then the expression can be considered polite. Conversely, if the expression does not provide an option to choose, then the speech is considered impolite.

\subsection{Scale of Sustainability}

This scale is explained that communication is done directly and indirectly. Communication indirectly is considered more polite, rather than done directly.

Based on the results of data analysis, found expressions that are considered to deviate from the scale of unsustainability in the film Uang Panai Mahar (L). The following snippet of conversation between characters in the following context: 


\section{Dialogue 11}

Inductive Information: When Risna listens to a song, which reminds her of her past with Anca. Where at that time, Anca wandered and left Risna in a long time and did not give news to Risna.

Risna : You are selfish. How did it come true! If the dream that you are after is just you leaving here!

Anca : Alright then. I will not leave you again.

The conversation above can be seen, that the phrase Risna is considered impolite, because it expresses words directly with great emotion. The more the speech is straightforward it will be considered the less polite the speech is. This is in line with what was expressed by (Rahardi, 2005) according to him the expression that was delivered indirectly, then the speech can be considered polite. Conversely, if the expression is delivered directly, then the speech can be considered impolite.

\section{Dialogue 12}

Indective Information: When Anca arrives at home, who has just returned from migrating. Immediately hugged by his mother. Then Tuming felt touched, and wanted to be hugged by his mother Anca.

Tuming : I also want to be hugged mama!

Anca's mother: The problem is that you are not my child.

The conversation above can be seen, that the expression Anca's mother is considered impolite, because expressing the word directly without thinking about the feelings of Tumming. The more the speech is straightforward it will be considered the less polite the speech is. This is in line with what was expressed by (Rahardi, 2005) according to him the expression that was delivered indirectly, then the speech can be considered polite. Conversely, if the expression is delivered directly, then the speech can be considered impolite.

\section{Dialogue 13}

Inductive Information: When Risna feels jealous seeing Anca, walks with another girl named Hasna. But Risna, did not know that Hasna was Anca's cousin.

$$
\begin{aligned}
& \text { Anca : Turns out you're here? } \\
& \text { Risna : Why? }
\end{aligned}
$$

The conversation above can be seen, that the phrase Risna is considered impolite, because it expresses words directly with great emotion. The more the speech is straightforward it will be considered the less polite the speech is. This is in line with what was expressed by (Rahardi, 2005) according to him the expression that was delivered indirectly, then the speech can be considered polite. Conversely, if the expression is delivered directly, then the speech can be considered impolite. 


\subsection{Social Distance Scale}

The social distance scale leads to the distance of the social distance between the speaker and the speech partner. If the social distance that is too far between the speaker and the interlocutor, then the communication will have the potential to be more polite. Conversely, if the close social distance between the speaker and the interlocutor, then the communication that takes place will potentially be impolite.

Based on the results of data analysis, found expressions that are considered to deviate from the authorization scale; scale of social distance in the film Uang Panai Mahar (L). The following snippet of conversation between characters in the following context:

\section{Dialogue 14}

Inductive Information: When Anca, Tuming, Abu are sitting at home. Then Anca wants to peel the mango.

\section{Tuming : You're in. Take it easy, lazy guy! \\ Abu : Do you not see me busy? Just use this!}

The conversation above contains a social distance scale deviation. This happens because the social distance is very close, so Tuming can say with a joke that is insulting or mocking his friend. The same thing was stated by Rahardi (2005) that there was a tendency for close social distance to cause impolite communication. Conversely, social distance that is too far will make the way of communication more polite.

\section{Dialogue 15}

Inductive Information: When Anca, Hasna, Tuming, and Abu will go to the café to watch live music. Then Hasna came out of the room dressed beautifully.

Tuming : This is amazingly Hasna. Prospective mothers for my children

Abu : Fix your mouth, use shampoo!

The conversation above contains deviations from the social distance scale. This happened because of the very close social distance, so Abu could say with a joke that was insulting or mocking his friend. The same thing was stated (Rahardi, 2005) that There is a tendency that close social distance will cause communication that is not polite. Conversely, social distance that is too far will make the way of communication more polite.

\section{Conclusion}

Based on the results of the data analysis above, a conclusion can be drawn that the deviations of politeness in language that occur in the Uang Panai Mahar (L) film are merely done to lead the audience to laugh. Considering this film is wrapped in a romantic comedy that elevates the local culture of the Bugis-Makassar tribe which is a requirement for moral messages. The language style that occurs in the film is very thick with the cultural dialect there. So that if viewed from another angle, as if the utterances of the characters in the film are considered less polite. However, due to the close social distance and also the dialect of the Sulawesi people in the diversity of Indonesia, so the sentences delivered are potentially less 
polite in the eyes of other tribes. Thus the deviation of politeness in language in the film Uang Panai Mahar (L) is deliberately done to improve the quality of the comedy-romantic type film.

Through this research it is expected that all the people, especially the Sulawesi people who are the object of research, will be able to speak with sentiment to achieve success in communication. Another goal is for filmmakers to be expected to create dialogue between characters using polite language. Given the influence of film today is very large in the development of life. Given the film is not solely as a medium of entertainment. More than that now the film has become a forum for education. Besides good films are films that can contribute to the audience.

\section{References}

Ardianto, E. (2004). Komunikasi massa suatu pengantar. Bandung: Simbiosa Rekatama Media.

Chaer, A. (2010). Kesantunan berbahasa. Jakarta: PT Rineka Cipta.

Ellen, G. (2001). Kritik teori kesantunan. (Jumadi dan Rianto, Slamet, penerjemah. 2006). Surabaya: Airlangga University Press.

Gunawan, F. (2014). Representasi Kesantunan Brown dan Levinson dalam wacana akademik. Kandai, 10(1), 16-27.

Jahdiah. (2016). Strategi permintaan dalam bahasa Banjar: Tinjauan kesantunan berbahasa. Kandai, 12(1), 37-49.

Kusmanto, H., Prayitno, H. J., \& Ngalim, A. (2019). Realisasi tindak kesantunan berbahasa pada komentar akun instagram Jokowi: Studi politikopragmatik. Kandai, 15(1), 47. https://doi.org/10.26499/jk.v15i1.1269

Lamallongeng, A. R. (2007). Dinamika perkawinan adat dalam masyarakat Bugis Bone. Kabupaten Bone: Dinas Kebudayaan \& Pariwisata Kabupaten Bone.

Leech, G. (1993). Prinsi-prinsip pragmatik. (M.D.D. Oka, penerjemah). Jakarta: Universitas Indonesia.

Lubis, H. H. (2015). Analisis wacana pragmatik. Bandung: Angkasa.

Markhamah \& Sabardila, A. (2009). Analisis kesalahan dan kesantunan berbahasa. Surakarta: Muhammadiyah University Press.

Mattulada. (1985). Latoa, suatu lukisan snalitis terhadap antropologi politik orang Bugis. Yogyakarta: Gadja Mada University Press.

Pranowo. (2009). Berbahasa secara santun. Yogyakarta: Pustaka Pelajar.

Pratista, H. (2008). Memahami film. Yogyakarta: Homerian Pustaka.

Rahardi, R. K. (2005). Pragmatik: Kesantunan imperatif bahasa Indonesia. Yogyakarta: Erlangga.

Slamet, S. Y. (2013). Bentuk tindak tutur direktif kesantunan berbahasa mahasiwa di lingkungan PGSD Jawa Tengah: Tinjauan sosiopragmatik. Widyaparwa, 41(November 2012), 41-52.

Sudaryanto. (1993). Metode dan aneka teknik analisis bahasa. Yogyakarta: Duta Wacana University Press.

Supriyadi, S. (2020). Pragmatic Analysis on G.M. Sudarta's Caricatures in Kompas Newspaper. Budapest International Research and Critics Institute-Journal(BIRCIJournal), P. 367-378.

Utami, S. R. (2017). Pembelajaran aspek tata bahasa dalam buku pelajaran bahasa indonesia. AKSIS: Jurnal Pendidikan Bahasa Dan Sastra Indonesia, 1, 189-203. https://doi.org/DOI: doi.org/10.21009/AKSIS.010203 
Watts, R. (2003). Politeness. Cambridge: Cambridge University Press.

Wijana, I. D. P. dan M. R. (2009). Analisis wacana pragmatik: Kajian teori dan analisis. Surakarta: Yuma Pustaka.

Zamzani, Tadkiroatun Musfiroh, Siti Maslakhah, Ari Listyorini, Y. E. R. (2011). Pengembangan alat ukur kesantunan bahasa Indonesia dalam interaksi sosial bersemuka dan nonbersemuka. LITERA, 10, 35-50. 